\title{
Lichenological excursion in North Africa. I. Silicicolous lichens in Morocco
}

\author{
J. M. EGEA \& J. G. ROWE
}

\section{Resumen}

EGEA, J. M. \& J. G. Rowe (1987). Excursión liquenológica en África del Norte. I. Liquenes silicícolas de Marruecos. Collect. Bot. (Barcelona) 17(1): 27-45.

Este trabajo contiene los primeros resultados florísticos de la excursión realizada a algunos puntos representativos de Marruecos. Se citan 110 táxones de líquenes de rocas ácidas, de los cuales 42 son, según nuestros datos, nuevas citas para Marruecos. Se sinonimizan dos táxones: Pertusaria ludovicae $\mathrm{R}$. G. Werner $\equiv P$. ceuthocarpoides Zahlbr. y Pertusaria rupicola (Fr.) Harm. var. bispora R. G. Werner $\equiv$ Pertusaria gallica B. de Lesd. Para cada uno de ellos se designa un lectótipo.

Palabras clave: Líquenes, nomenclatura, corología, Norte de África.

\section{Summary}

EgEA, J. M. \& J. G. Rowe (1987). Lichenological excursion in North Africa. I. Silicicolous lichens from Morocco. Collect. Bot. (Barcelona) 17(1): 27-45.

This work summarizes the first floristic results of a lichenologic excursion through some representative localities of Morocco. From the 110 silicicolous species recognized, 42 are, after our information, new to Morocco. Synonymy of 2 taxa is established: Pertusaria ludovicae $\mathrm{R}$. G. Werner $=P$. ceuthocarpoides Zahlbr. and Pertusaria rupicola $(\mathrm{Fr}$.) Harm. var. bispora R. G. Werner = Pertusaria gallica B. de Lesd. These two last species are lectotypified.

Keywords: Lichenes, nomenclature, chorology, North Africa.

\section{INTRODUCTION}

In April 1984 we undertook a lichenological excursion to various coastal and inland localities in Morocco. Those taking part were: S. Silvestre, A. Aparicio (Seville) and D. Rivera (Murcia) for the study of vascular flora and R. Ros (Murcia) for the study of bryophytes. One of the team members (Egea) was in charge of organization.

This was the first of a series of scientific expeditions outside our main area of study (south

J. M. Egea: Departamento de Botánica. Facultad de Biologia. Universidad de Murcia. 30001 Murcia. J. G. RowE: Departamento de Botánica. Facultad de Farmacia. Universidad de Sevilla. 41012 Sevilla. 
and south eastern Spain) which aims to cover the western Mediterranean region and the northern Sahara. The main objective is to contribute to knowledge of lichenous flora and vegetation in this large area and to acquire an overall picture of western Mediterranean lichens.

The flora of Morocco is relatively well known, thanks to the extraordinary work accomplished by WERNER (1901-1977). His vast bibliography, which was classified by LLIMONA (1979), comprises over sixty articles devoted to the floristic and chorological study of lichens in Morocco. The data contributed by Werner is supplemented by other authors such as: BouLY \& Pitard (1913), Bouly (1924), Maheu \& Gillet (1924, 1925), Maheu (1928), Szatala $(1929,1931)$, TROTET (1965) and ASTA \& col. (1972).

In this first article we present the first floristic and chorological results referring to lichens living on acid rocks. Future research will be devoted to calcicolous lichens and epiphytes and certain species which raise taxonomical or bibliographical problems. The phytosociological conclusions will be the subject of a later study spanning much of the Mediterranean region.

\section{Localities studied}

1. Cape Spartel (Tangier). Altitude: $30-100 \mathrm{~m}$ above sea level. Substratum: schist of variable consistency. Potential vegetation: Phillyreo angustifoliae-Quercetum fruticosae Barbero, Quézel \& Rivas Martínez 1981. Belt: thermo-Mediterranean. Ombroclimate: sub-humid.

2. Abssanaoubar Beach (Bouznika). Altitude: $60 \mathrm{~m}$ above sea level. Substratum: Schists. Potential vegetation: Clematidi cirrhosae-Juniperetum lyciae Barbero, Quézel \& Rivas Martínez, 1981. Belt: thermo-Mediterranean. Ombroclimate: dry.

3. Pont Blondin (Mohammedia). Altitude: $20 \mathrm{~m}$ above sea level. Substratum: schists. Potential vegetation: Clematidi cirrhosae-Juniperetum lyciae Barbero, Quézel \& Rivas Martínez, 1981. Belt: thermo-Mediterranean. Ombroclimate: dry.

4. El Djebilet Base (between Kettara and Marrakech). Altitude: $500 \mathrm{~m}$ above sea level. Substratum: micaschists. Potential vegetation: xerophilous series of Pistacia atlantica and Ziziphus lotus Bendabid 1982. Belt: thermo-Mediterranean. Ombroclimate: sub-arid.

5. Ourika Valley. Dar Caid Ouriki (High Atlas). Altitude: $800 \mathrm{~m}$ above sea level. Substratum: micaschists. Potential vegetation: Polygalo balansae-Tetraclinidetum articulatae Barbero, Quézel \& Rivas Martínez 1981. Belt: thermo-Mediterranean. Ombroclimate: dry.

6. Ourika Valley. Setti Fatma (High Atlas). Altitude $1300 \mathrm{~m}$ above sea level. Substratum: Hercynian granites and schists. Potential vegetation: Luzulo atlanticae-Quercetum rotundifoliae Achal, Barbero, Quézel \& Rivas Martínez 1981. Belt: meso-Mediterranean. Ombroclimate: sub-humid.

7 and 8. Oukaimeden (High Atlas). Altitude: 2300-2600 m above sea level. Substratum: Hercynian granites and schists. Potential vegetation: Juniperus thurifera community. Belt: oro-Mediterranean. Ombroclimate: dry.

9. $1 \mathrm{~km}$ south west of El Keláa des Srarhna. Altitude: $600 \mathrm{~m}$ above sea level. Substratum: micaschists. Potential vegetation: community of Pistacia atlantica and Ziziphus lotus (Benabid 1982). Belt: thermo-Mediterranean. Ombroclimate: semi-arid.

10 and 11. Azrou-Ifrane. Altitude: $1250-1400 \mathrm{~m}$ above sea level. Substratum: basalt and micaschists. Potential vegetation: Balansaeo glaberrimae-Quercetum rotundifoliae Barbero, Quézel \& Rivas Martínez 1981. Belt: meso-Mediterranean. Ombroclimate: sub-humidhumid.

12. Azrou-Toumliline. Altitude: $1700 \mathrm{~m}$ above sea level. Substratum: silicates and basalt. Potential vegetation: Balansaeo glaberrimae-Cedretum atlanticae Barbero, Quézel \& Rivas Martínez 1981. Belt: montane Mediterranean. Ombroclimate: sub-humid-humid.

13. Mischliffen (Azrou). Altitude: $2200 \mathrm{~m}$ above sea level. Substratum: Basalt. Potential 


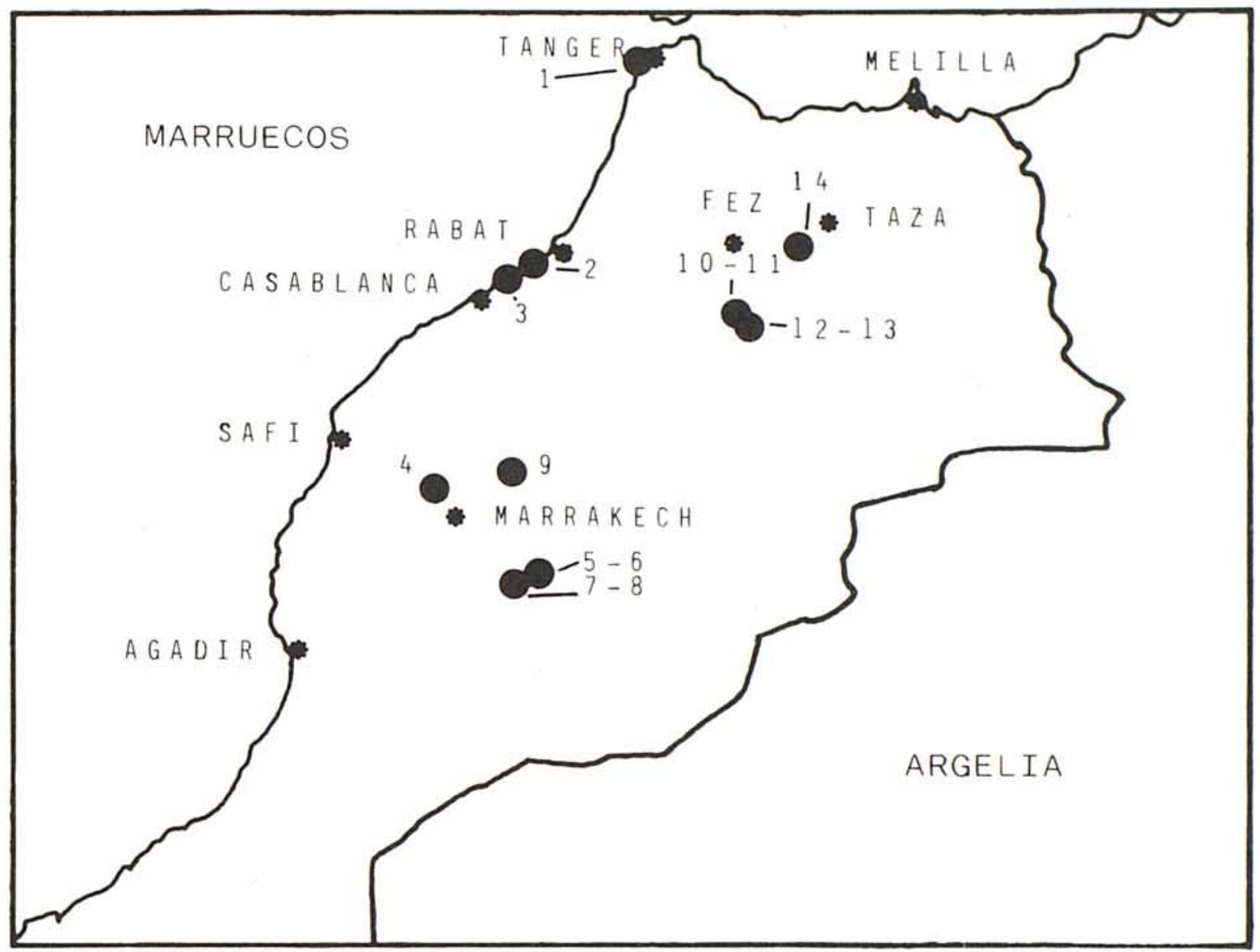

Fig. 1.- Localities studied.

vegetation: Balansaeo glaberrimae-Cedretum atlanticae Barbero, Quézel \& Rivas Martinez 1981. Belt: montane Mediterranean. Ombroclimate: sub-humid-humid.

14. Djebel Tazzeka, between Sidi Abdallah and Bad Bou Idir (Taza). Altitude: $1400 \mathrm{~m}$ above sea level. Substratum: Silurian schists and basalts. Potential vegetation: Balansaeo glaberrimae-Quercetum rotundifoliae Barbero, Quézel \& Rivas Martínez 1981, subass. centauretosum taganae Barbero, Quézel \& Rivas Martínez 1981. Belt: meso-Mediterranean. Ombroclimate: sub-humid.

\section{Climate}

The main features of the climate in locations close to the coast are a single period of maximum rainfall in winter and almost complete drought in summer. In inland and mountainous zones, the climate usually comprises of two rainy seasons, spring and autumn.

The climate diagrams drawn up by WALTERS \& col. (1975) show a gradual decrease in rainfall from north to south, both on the west coast (Tangier $887 \mathrm{~mm}$, Rabat $523 \mathrm{~mm}$, Mazagan $336 \mathrm{~mm}$ ) and inland (Taza $670 \mathrm{~mm}$, Fes $545 \mathrm{~mm}$, Marrakech $286 \mathrm{~mm}$ ). Average temperatures range from $17^{\circ}$ to $20^{\circ} \mathrm{C}$, (Tangier $17,4^{\circ} \mathrm{C}$, Mazagan $17,1^{\circ} \mathrm{C}$, Taza $17^{\circ} \mathrm{C}$, Marrakech $20^{\circ} \mathrm{C}$ ) except in mountainous areas about which we have no data but where they are probably somewhat lower. 


\section{Method}

Generally speaking the following works were used to identify the material: OzENDA \& Clauzade (1970), Poelt (1969), WirTh (1980), EgEA \& Llimona (1981). For specific groups we consulted other works including: Acarospora (CLAUZADE \& RouX, 1981); Caloplaca (EgeA, 1984); Heppia and Peltula (WeTMORE, 1970; SwINSCOW \& KROG, 1979); Rinodina (MAYrhofFer \& PoElt, 1977; MAYRHOFFER, 1984); Pertusaria (DibBEN, 1980).

The nomenclature used is that proposed by HAwKSWORTH, JAMES \& COPPINS (1980), except in special cases when we referred to SANTESSON (1984) and the works already quoted for identification purposes. The distribution is based on: WIRTH (1980), GALUM (1970) and on our own observations.

The data regarding previous reports in Morocco of the taxa listed in the floristic catalogue were obtained from the file compiled by Llimona (Barcelona) which covers virtually all scientific articles published on lichens in North Africa.

\section{FLORISTIC CATALOGUE}

In this catalogue taxa are listed in alphabetical order. Localities are indicated by means of the corresponding number. Species marked with an asterisk $\left(^{*}\right)$ may be considered new reports for the flora of Morocco.

\section{* Acarospora charidema (Clem. ex Colmeiro) Llimona} Loc. 4, 9 .

On moderately sloping surfaces in sunny spots. Thermo-, xero-, helio-, ombrophilous. Known on the south east coast of Spain between Cabo de Palos (Murcia) and Cabo Sacratif (Granada). Spreads inland to close to Puerto Lumbreras (Murcia) and the foot of the Sierra de los Filabres (Almería). Its localization in Morocco considerably widens the distribution area of this taxon. Optimum in the thermo-Mediterranean semi-arid belt.

\section{Acarospora complanata H. Magn.}

Loc. 11.

On basalt, $1300 \mathrm{~m}$ above sea level. Nitrophilous. Known in Morocco in the Middle Atlas and Anti-Atlas over $1600 \mathrm{~mm}$ above sea level.

* Acarospora epithallina H. Magn.

Loc. 9.

Parasite on the thallus of Acarospora hilaris. Taxon known only in the Iberian Peninsula and Sicily. Optimum in the meso-Mediterranean belt.

Acarospora fuscata (Nyl.) Arnold

Loc: $2,7,8,9,13$.

Nitrophilous. Indifferent to altitude and exposure, though it prefers sunny spots exposed to rain. Sub-cosmopolitan. Widespread in Morocco.

Acarospora hilaris (Duf.) Hue

Loc. $4,9$.

On sheer or overhanging south east facing surfaces. Thermo-, helio-, photophilous, ombrophobe. Known in the Mediterranean region (Iberian Peninsula, southern France, Italy, 
etc.). Reported in Marocco around Boulhaut, Rabat and Mount Siroua. This last reference, at $2600 \mathrm{~m}$ above sea level, seems to us somewhat doubtful. Optimum in the meso-Mediterranean belt.

Acarospora impressula Th. Fr.

Loc. 8.

On slightly sloping rocky surfaces in sunny spots. Invades the thallus of other lichens. Orophilous. Frequent in the Northern Hemisphere. Found in the western Mediterranean region over $1700 \mathrm{~m}$ above sea level.

Acarospora maroccana B. de Lesd.

Loc. 4, 6, 9.

On surfaces of varying inclinations in sunny spots. Thermo-, xero-, helio-, ombrophilous. Known in south eastern Spain and Morocco. Optimum in the thermo-Mediterranean semi-arid and dry belt. Penetrates locally into the lower part of the meso-Mediterranean belt.

Acarospora microcarga (Nyl.) Wedd.

Loc. 4.

Parasite of Diploschistes actinostomus. Known in south eastern Spain, southern France and Greece. Reported in Morocco near El Kelaa and in the Djbillet. Optimum in the thermo-Mediteranean belt.

Acarospora nodulosa (Duf.) Huer var. reagens Clauz. \& Roux Loc. 6.

On somewhat altered schist rocks with accumulated soil. Frequent in Morocco.

* Acarospora picea H. Magn.

Loc. 7.

On horizontal sunny surfaces. Oro-, helio-, nitrophilous. Previously reported in Spain (Sierra Nevada) and Central Asia (Pamir).

Acarospora sulphurata (Arnold) Arnold Loc. 7, 8, 13.

Acts as a pioneer in the colonization of rocks protruding horizontally close to the surface of the ground in sunny positions. Oro-, helio-, ombro-, nitrophilous. Optimum in the Mediterranean region above the meso-Mediterranean belt. Known in all the high mountains in Morocco except Er Rif.

\section{Acarospora umbilicata Bagl.}

Loc. 4.

On acid, neutral or slighly basic, non-carbonated rocky surfaces. Thermo-, helio-, nitrophilous. Known in the Eurosiberian, Mediterranean and Macaronesic regions. In the Mediterranean region its optimum is in the thermo- and meso-Mediterranean belt, with sub-arid and dry ombroclimate. Known in Morocco in Taza and the Anti-Atlas (Ait Baha).

Anaptychia ciliaris (L.) Körber.

Loc. 6, 13.

On schists and basalts. Aerohygro-, nitrophilous. Fairly common in the Northern Hemisphere except in the most arid, dry zones. Indifferent to altitude and substratum. 


\section{* Arthopyrenia halodytes (Nyl.) Arnold}

Loc. 1.

Common on the Atlantic and Mediterranean coasts. On the sheil of acorn barnacles (Balanus balanoides) and limestone rocks in the supralittoral zone.

* Aspicilia epiglypta (Norrl.) Hue

Loc. 13.

On slightly sloping surfaces in sunny locations. Helio-, ombro-, nitrophilous. Known in Europe and Boreal Asia. Relatively common in the Mediterranean region from the meso- to the crioro-Mediterranean belt.

Aspicilia polychroma Anzi subsp. polychroma

Loc. 8.

On rocks of varying inclinations in sunny locations. Known in Morocco in the Oued Nefifik, on the road from Rabat to Casablanca (doubtful reference).

Aspicilia radiosa (Hofm.) Schaerer

(including Lecanora subcircinata Nyl. sensu Ozenda \& Clauzade, 1970).

Loc. 5, 8, 9, 14.

On slightly sloping rocks exposed to sun and rain. Nitrophilous. Indifferent to altitude.

Buellia cerussata Llimona \& R. G. Werner

Loc. 1.

Establishes itself on the crests of horizontal rocks exposed to sun and on the upper part of subvertical north-facing rock faces. Thermophilous, heliophilous to heliophobe, photophilous, ombrophilous. Know in the western Mediterranean region (southern France, southern and south eastern Spain, Portugal) and in the Macaronesic region. Optimum on the coast of the thermo-Mediterranean and infra-Canarian belt.

* Buellia glaucoatra (Nyl.) Clauz. Loc. 1.

On surfaces of varying inclinations in sunny spots. Thermo-, photo-, ombrophilous. Known on the coast of the western Mediterranean region and western France.

* Buellia lactea (Massal.) Körber.

Loc. 2, 4, 6 .

Colonizes surfaces of varying inclinations, in sunny or sheltered spots. Optimum in the thermo- and meso-Mediterranean belt and in the Macaronesic region.

Buellia punctata (Hoffm.) Massal.

Loc. 1.

Nitrophilous. Indifferent to altitude and substratum. Cosmopolitan.

* Buellia subdisciformis (Leight.) Vain.

Loc. 1.

On rock faces of varying inclinations in sheltered spots. Heliophobe, photophilous, ombrophilous. Known on the coast of the Eurosiberian, Mediterranean and Macaronesic regions. 
* Caloplaca aractina (Fr.) Hyren.

Loc. 1 .

On shaded vertical rock faces. Heliophobe, photophilous, ombrophilous.

* Caloplaca biatorina (Massal.) Steiner

Loc. 13.

On basalt. Orophilous, ombrophobe. Known in the Alpine and pre-Alpine belts of the Eurosiberian region and on the supra-, oro- and crioro-Mediterranean belts.

Caloplaca carphinea (Fr.) Jatta

Loc. 2,4 .

On fairly compact rocks on south-facing surfaces ranging from horizontal to supervertical. Helio-, photo-, and mainly ombronitrophilous. Optimum in the meso-Mediterranean belt. Common in Morocco.

Caloplaca conglomerata (Bagl.) Jatta Loc. 2, 9, 14.

On slightly sloping, very sunny surfaces. Helio-, photo-, and mainly ombronitrophilous. Optimum in the meso-Mediterranean belt. Common in Morocco.

Caloplaca conglomerata (Bagl.) Jatta

Loc. 2, 9, 14.

On slightly sloping, very sunny surfaces. Helio-, photo, nitrophilous. Optimum in the thermo- and meso-Mediterranean belts. Quoted in Werner's bibliography as C. squamulosa (Wedd.) B. de Lesd.

* Caloplaca conversa (Krempelh.) Jatta

Loc. 2, 6, 8, 9, 14.

On slightly slanting rocks and drainage surfaces. Nitro-, helio-, ombrophilous. Central European-Mediterranean.

Caloplaca erythrocarpa (Pers.) Zw.

Loc. 6.

On altered schists presenting slight effervescence due to acids. Optimum in the Mediterranean region. Penetrates into temperate places in the Eurosiberian region.

Caloplaca festiva (Ach.) Zw.

Loc. 3 and 14.

Nitro-, photo-, ombrophilous. Indifferent to altitude and exposure though it prefers surfaces with little sun. Very common in Morocco.

* Caloplaca inconnexa (Nyl.) Zahlbr.

Loc. 4.

On drainage surfaces. Optimum in the thermo- and meso-Mediterranean belts.

* Caloplaca irrubescens (Nyl.) Zahlbr.

Loc. 9, 10, 14. 
On slightly sloping surfaces in sunny spots. Calcifuge, thermo-, helio-, nitrophilous. Optimum in thermo- and meso-Mediterranean belts, reaches as far as the southern Eurosiberian region.

* Caloplaca subpallida H. Magn.

Loc. 8.

Indifferent to altitude. Calcifuge, helio-, nitrophilous. Common all over Europe.

Caloplaca velana (Massal.) Du Rietz.

Loc. 8.

On rocks in sunny locations presenting slight effervescence due to acids. Mainly calcicolous, nitrophilous. Widespread in the Eurosiberian and Mediterranean regions.

* Candelariella vitellina (Ehrt) Müll. Arg.

Loc. 2, 4, 13.

Indifferent to altitude and substratum. Nitro-, helio-, ombrophilous. Cosmopolitan.

Catacyrenium lachneum (Ach.) R. Sant.

Loc. 6.

In cracks in rocks where a certain amount of soil accumulates. Subcosmopolitan. Common in Morocco.

Catillaria chalybeae (Borr.) Massal.

Loc. 1, 3, 11 .

On sloping surfaces in places not exposed to the sun. Indifferent to altitude and substratum. Heliophobe, photophilous. Sub-cosmopolitan. Known in Morocco on Cape Spartel (Tangier).

Dermatocarpon miniatum (L.) Mann. var. cirsodes Ach.

Loc. 6.

On sheer rock faces with numerous cracks through which water oozes after rain. Subcosmopolitan. Common in the Mediterranean region, except in the thermo-Mediterranean belt. Known in Morocco in the Atlas mountains.

Dimelaena oreina (Ach.) Norm.

Loc. 6, 7, 8 .

On surfaces with varying degrees of slant, in sunny spots. Helio-, ombro-, heminitrophilous. Widespread in the Northern Hemisphere. In the Mediterranean region its optimum is above the meso-Mediterranean belt.

Diploicia subcanescens (R. G. Werner) Hafellner \& Poelt Loc. 1.

Thermo-, xerophilous, indifferent to exposure and light, though it behaves mainly as a heliophobe. Optimum on the coast of the western Mediterranean (Spain and France) and Macaronesic regions. Known in Morocco in the Anti-Atlas (Grizin).

* Dirina repanda (Ach.) Fr. var. schistosa Bagl.

Loc. 1,3 . 
On vertical or supervertical surfaces in shady spots. Thermophilous, heliophobe, ombrophobe, indifferent to light. Optimum on the shore of the Mediterranean and Macaronesic regions.

\section{* Gonohymenia algerica Stnr.}

Loc. 4, 6, 9, 10.

In cracks through which water drains. Thermo-, xero-, helio-, nitrophilous. Known in Algeria and Tunisia.

* Heppia turgida (Ach.) Nyl.

Loc. 10.

In cracks in rocks where particles of soil accumulate. Along the coastline of the Mediterranean and Macaronesic regions.

* Lecanactis monstrosa Bagl.

Loc. 1.

On overhanging shady surfaces, and in the entrance or on the roof of small caves or hollows. Thermophilous, heliophobe, ombrophobe, sciaphilous. Optimum on the coast of the western Mediterranean and Macaronesic regions.

Lecanactis patellarioides (Nyl.) Vain.

Loc. 1.

On shady surfaces. Indifferent to substratum. Previously known in Morocco as an epiphyte on the Atlantic coast.

* Lecanactis plocina (Ach.) Massal.

Loc. 1.

On overhanging, shady surfaces. Common in the Eurosiberian, Mediterranean and Macaronesic regions.

Lecanora albescens (Hoffm.) Floerke

Loc. 1.

On horizontal rocks jutting out from the ground. Cosmopolitan.

Lecanora altra (Huds.) Ach.

Loc. 10.

Indifferent to altitude, substratum and exposure. Photo-, hemi-, nitrophilous. Cosmopolitan.

\section{* Lecanora caesiosora Poelt}

Loc. 7.

On vertical or overhanging rock faces, both south-and north-facing. Oro-, photophilous, ombrophobe. Boreo-Alpine, oro-Mediterranean.

Lecanora campestris (Schaer.) Hue

Loc. 1, 3, 5, 14.

On horizontal or slightly sloping rocks in sunny spots. Helio-, photo-, nitrophilous. Cosmopolitan. Widespread in Morocco. 


\section{* Lecanora cenisia Ach.}

Loc. 7.

On vertical or overhanging rock faces with little sun. Heliophobe, photophilous. Common in the Northern Hemisphere. Grows in the Mediterranean region above the meso-Mediterranean belt.

Lecanora diffracta (Poetsch.) Ach.

Loc. 11, 13.

On horizontal rocks protruding from the ground in sunny spots. Helio-, ombro-, nitrophilous. Common in Morocco.

Lecanora dispersa (Pers.) Röhl.

Loc. 6.

Nitrophilous. Indifferent to altitude. Cosmopolitan.

Lecanora frustulosa (Dicks.) Ach.

Loc. 8, 13.

On horizontal surfaces in sunny locations. Oro-, helio-, ombro-, nitrophilous. ArcticAlpine distribution. Penetrates into the high mountains or the western Mediterranean region. Reported by WERNER (1955) in Morocco in the Oued Bouznika on the road to Casablanca, a report which seems to us somewhat doubtful.

Lecanora gangaleoides $\mathrm{Nyl}$.

Loc. 13.

Establishes itself mostly on vertical or subvertical surfaces with little sun. Heliophobe, photophilous, ombrophilous. Frequent in the Eurosiberian and Mediterranean regions. Previously known in Morocco on Cape Spartel and in the Djebel Moussa (Tangier).

* Lecanora laatokaensis (Räs.) Poelt

Loc. 13.

Colonizes the crests of rocks and spreads to the upper part of north-facing rock slabs.

Lecanora montagnei (Fr.) Schaer.

Loc. 1 .

On surfaces of varying inclinations in sunny spots. Western coast of the thermoMediterranean belt. Known in Morocco in Fedala and Bou Regreg (south of Rabat).

Lecanora muralis (Schreb.) Rabenh.

Loc. 2, 5, 11, 15.

Heliophilous, nitrophilous, indifferent to altitude. Cosmopolitan.

Lecanora muralis (Schreb.) Rabenh. var. dubyi (Müll. Arg.) Poelt Loc. 7, 12, 13 .

Heliophilous, nitrophilous. Common in the Eurosibérian and Mediterranean regions.

Lecanora rupicola (L.) Zahlbr.

Loc. 7, 8, 13. 
On surfaces of varying inclinations, both south- and north-facing. Photophilous. Frequent in Morocco.

* Lecanora schistina (Nyl.) Arnold

(= L. praepostera Nyl. Ozenda \& Clauzade, 1970).

Loc. 1.

On vertical or steeply sloping surfaces in sheltered places. Heliophobe, photophilous. Common along the coast of the western Mediterranean and Macaronesic regions.

\section{* Lecidea conferenda Nyl.}

Loc. 7, 8.

Behaves as a pioneer in the colonization of horizontal rocks jutting out slighlty above ground level. In mountains and cold regions of the Northern Hemisphere over $800 \mathrm{~m}$ above sea level.

Lecidea fuscoatra (L.) Ach.

Loc. 12.

On slightly sloping surfaces in sunny spots exposed to rain. Helio-, ombro-, nitrophilous. Sub-Boreo-Mediterranean. Known in Morocco in the Er Rif (Bab Taza and Djebel Kessana) and on Mount Siroua.

Lecidea fuscoatra (L.) Ach. var. grisella (Floerke) Nyl.

Loc. 10, 14.

On horizontal rocks jutting out of the ground. Helio-, ombrophilous. Central EuropeanMediterranean. Previously known in Morocco in Bou Regreg (south of Rabat).

\section{Lecidea tessellata Floerke}

Loc. 7.

On vertical rocks, in paces with little sun. Heliophobe, photophilous. Arctic-Alpine, penetrates into the high mountains of the Mediterranean region. Known in Morocco in the Anti-Atlas (Mount Lekst, 2000-2300 m above sea level).

Lecidella carpathica Körber.

Loc. 7, 8, 10, 13.

On sunny, slightly sloping surfaces. Sometimes penetrates into communities on northfacing slopes. Arctic-Mediterranean. Known in the Middle Atlas and Er Rif.

* Lecidella subincongrua (Nyl.) Hertel \& Leuckert

Loc. 2, 5 .

On slightly sloping surfaces, both north- and south-facing. Boreo-Mediterranean.

\section{Lichinella stipatula Nyl.}

Loc. 2, 4, 6, 9, 14.

On drainage surfaces over which water trickles after rain and where it may also condense as dew. Varying exposures. Optimum in the thermo- and meso-Mediterranean belts. Known in Tangier (Mount Kebir). 
* Opegrapha lutulenta Nyl.

Loc. 1,3 .

Optimum on vertical and overhanging north-facing surfaces. Heliophobe, from photophilous to sciophilous, ombrophobe. Know on the coast of the western Mediterranean region (Italy, France, and Spain).

\section{* Opegrapha subelevata Nyl.}

Loc. 3 .

On vertical, north-facing rocks. Heliophobe, photophilous, ombrophobe. Known in the western Mediterranean region (Italy, France, Spain, Algeria).

Parmelia conspersa (Ach.) Ach.

Loc. 14.

Usually on gently sloping, sunlit surfaces exposed to rain. Nitrophilous. Sub-cosmopolitan. Common in Morocco.

* Parmelia infumata Nyl.

Loc. 13.

On gently sloping, eruptive rocks in sunny spots. Nitrophilous. Artic-Alpine-oroMediterranean.

\section{Parmelia pulla Ach.}

Loc. 4.

Finds its optimum on flat or slightly sloping surfaces in sunny spots. Nitrophilous. Sub-Boreo-Mediterranean.

Parmelia tiliacea (Hoffm.) Ach.

Loc. 5.

On vertical or overhanging rock faces in generally shady places. Indifferent to substratum. Sub-cosmopolitan.

Parmelia tinctina Maheu \& Gillet

Loc. 2, 4, 9 .

On flat or slightly sloping surfaces, exposed to sun and rain. Nitrophilous. Optimum in coastal or sublittoral Mediterranean and Atlantic mountains.

\section{* Parmelia verruculifera Nyl.}

Loc. 14.

On flat or slightly sloping sunlit surfaces exposed to rain. Nitrophilous. Central EuropeanMediterranean.

Peltula euploca (Ach.) Poelt

Loc. 2, 4, 6, 9, 14.

On drainage surfaces over which water flows after rain and where condensation may form as dew. Various exposures. Optimum between the infra- and meso-Mediterranean and infraand thermo-Canarian belts. Reaches as far as southern central Europe. In Morocco it was 
known in Tangier, Souk el Arba (Rehamna), Tizi Aferni (Anti-Atlas) and the Lower Dra (SW Morocco).

Peltula obscurans (Nyl.) Gyel.

Loc. 9.

Same ecology as the preceding species. Optimum in infra- and thermo-Mediterranean and infra-Canarian belts. Frequent in Morocco.

Petula omphaliza (Nyl. in Eckf.) Wetm.

Loc. 2, 9 .

Similar ecology to the preceding species. Optimum in the thermo-Mediterranean belt of the western Mediterranean region (Italy, France and Spain).

WERNER (1956) describes Heppia subgnepinii in the Anti-Atlas. After studying the scanty type specimen material available in BC, SwINSCOW \& KROG (1979), believe that it may be considered synonymous with Peltula euploca. We are of the opinion that, in view of the absence of marginal soralios, $H$. subgnepinii should be considered synonymous with $P$. omphaliza, a taxon which is always found alongside $P$. euploca in southern and south eastern Spain.

Pertusaria ceuthocarpoides Zahlbr., Catal. Lich. Univ. 5: 128 (1928) (= P. leudovicae R. G. Werner, Bull. Soc. Sci. Nat. Maroc, 16 (1): 93 (1936). Type: Morocco, Tangier, Cape Spartel, Werner, 12-6-1934 (type specimen: BC-Werner).

Loc. 1.

On surfaces of varying inclinations, facing north or west. In places where atmospheric humidity is high, it colonizes sheer sunlit rock faces. Aerohygrophilous. Widespread on the Mediterranean and Atlantic coasts with sub-humid and humid ombroclimate.

In the Werner herbarium, deposited at the Institut Botànic de Barcelona (BC), there are two specimens of $P$. leudovicae collected by Werner on Cape Spartel. Both coincide perfectly with the original description. One of us (Egea) has designated as type specimen the specimen marked "Lichens maroccani. Pertusaria leudovicae Wern. Ad Saxa arenosa Promontori Tingitani Spartel denominati. Coll. R. G. Werner 12-6-1934".

Pertusaria gallica N. de Lesd., Bull. Soc. Bot. France 72:788 (1925) (= P. rupicola (Fr.) Harm. var. bispora R. G. Werner, Bull. Soc. Sci. Maroc. 16 (1): 94 (1936). Type: Morocco, Tangier, Cape Spartel, Werner, 13-7-1936. Type specimen: BC-Werner).

Loc. 1.

Same ecology as the preceding species. Coast of the western Mediterranean and Macaronesic regions.

In the Werner herbarium mentioned above, three specimens of this taxon have been found. Two were collected on Cape Spartel (one accompanied by Rinodina confragosa (Ach.) Kerber) and the other near Gibraltar. One of us (Egea) has designated as type specimen the specimen from Cape Spartel without Rinodina confragosa. "Sur grès au Cap Espartel près Tanger 13-7-1936".

\section{Pertusaria leucosora Nyl.}

Loc. 5.

On vertical or subvertical north-facing surfaces. Central European-sub-Atlantic-Mediterranean. Known in Morocco in the Oued Nefifik (near Boulhaut). 
* Pertusaria monogona Nyl.

Loc. 1.

On vertical or subvertical north-facing surfaces. Aerohygrophilous. Widespread on Mediterranean coastlines.

Physcia albinae (Ach.) Nyl. em Frey

Loc. 7.

On vertical or overhanging rock faces and in cracks where soil accumulates in sheltered places. Optimum in the supra-, oro-, crioro- Mediterranean and supra-Canarian belts. Taxon reported in the south east of Spain (EGEA \& LLIMONA, 1981 and EGEA \& col. 1982) as Physcia magnussonii Frey. Known in Morocco in the Middle Atlas (Tiounliline, $1500 \mathrm{~m}$ above sea level).

* Polysporina simplex (Davies) Vêzda

Loc. 7.

Usually on gently sloping surfaces in sunny spots with many small cracks in which a little soil and humidity accumulates. Helio-, ombro-, nitrophilous. Frequent in the Northern Hemisphere.

\section{* Psorotichia frustulosa Anzi Loc. 6, 9.}

On sunlit drainage surfaces.

Psorotichia suffugiens (Nyl.) Forss.

Loc. 9.

Same ecology as the preceding species. Widespread in the western Mediterranean region.

* Pyrenopsis triptococca Nyl.

Loc. 2, 9.

Same ecology as the preceding species. Known in Spain and Portugal.

Ramalina bougeana (Mont.) Nyl.

Loc. 1.

Optimum in rocks cracks in coastal mountains. Also tolerates the upper part of blocks in places sheltered from direct sunlight. Ornitocoprophilous; photo-, ombro-, xerophilous. Plentiful on the coast of the western Mediterranean and Macaronesic regions.

* Ramalina digetellata Nyl.

Loc. 7, 8, 13.

Found on the upper part of vertical or overhanging boulders exposed to the sun. Widespread in the western Mediterranean region above the thermo-Mediterranean belt.

Rhizocarpon viridiatrum (Wulf.) Koerb.

Loc. 1.

Parasite of Pertusaria gallica. Sub-cosmopolitan.

Rhizoplaca chrysoleuca (Smith) Zopf.

Loc. $7,8$. 
The thallus forms thick cushions in cracks in horizontal or nearly horizontal rocks. It is also common on the upper part of vertical or supervertical boulders in sunny spots. Oro-, ornitocopro-, helio-, photophilous. Artic-Alpine-oro-Mediterranean. In Morocco it was already known in the High Atlas.

Rhizoplaca melanophthalma (Räm.) Leuckert \& Poelt

Loc. 7.

Same ecology and distribution as the previous species.

Rhizoplaca peltata (Räm.) Leuckert \& Poelt

Loc. 7.

Same ecology as the previous species. Alpine-oro-Mediterranean. Common in the Atlas mountains.

\section{Rinodina alba Metzler ex Arnold}

Loc. 1.

On surfaces of varying inclinations in places with little sun. Heliophobe, photo-, ombrophilous. Widespread in the coastal mountains of the Mediterranean and Macaronesic region. In Morocco it was known in the western Er Rif (Djebel Khessana, $1300 \mathrm{~m}$ above sea level).

Rinodina lecanorina (Massal.) Massal.

Loc. 10.

On slightly sloping, eruptive rocks with eroded surfaces close to the ground in sunlit spots. Widespread in the Eurosiberian and Mediterranean regions, on calcareous and dolomitic rocks.

Ridonina subglaucescens (Nyl.) Sheard.

Loc. 1.

On rocks of varying inclinations with little sun near the coast. Heliophobe, thermo-, photo-, ombrophilous. Plentiful on the coast of the Mediterranean, Macaronesic and southern Eurosiberian regions.

\section{Rinodina techophyla (Nyl.) Arnold}

Loc. 13.

On eruptive rocks in sunny spots. Eurosiberian and Mediterranean regions. Known in Morocco in the Er Rif (Bab Taza).

* Rinodina trachytica (Massal.) Bagl. \& Car.

Loc. 14.

On altered eruptive rocks close to the ground. Central European-Mediterranean.

Roccella fuciformis (L.) DC.

Loc. 3.

On vertical, subvertical and sometimes overhanging surfaces with little or no sun. Aerohigrophilous, heliophobe, photophilous. Optimum on the Atlantic coast, less frequent on the shore of the Mediterranean. 
Roccella phycopsis (Ach.) Ach.

Loc. 1, 3 .

Same ecology as the preceding species. Widespread on the Atlantic and Mediterranean coasts. On all types of substrata.

* Roccella vicentina (Vain) Vain.

Loc. 1,3 .

Same ecology as the two preceding species. Frequent along the coastline of the Mediterranean and Macaronesic regions.

Toninia cinereovirens (Schaer.) Massal.

Loc. 2, 9, 10.

On drainage surfaces. Mediterranean and Macaronesic regions. Known in Morocco in Ifrane, Fès and the Bouznika area.

*Toninia opuntioides (Vill.) H. Baumg.

Loc. 6, 14.

In cracks in rocks where incipient soil accumulates.

* Umbilicaria vellea (L.) Ach. em Frey. Loc. 7.

Establishes itself on the upper part of vertical boulders, in sunny spots. Orophilous. Arctic-Alpine, oro-Mediterranean.

* Verrucaria amphibia R. Clem.

(=V. symbalana $\mathrm{Nyl}$.)

Loc. 1.

Forms an almost continuous black band in some parts of the supralittoral zone. Indifferent to exposure. Frequent on the Atlantic and Mediterranean coasts.

Verrucaria lecideoides (Massal.) Trev. var. minuta (Hepp.) Zsch.

Loc. 9.

Mediterranean region, penetrates into some parts of the Eurosiberian region. Known in Morocco in Fès, Taza and Berguent.

\section{Verrucaria sphaerospora Anzi}

Loc. 13.

In cracks in the rock where particles of soil accumulate. Optimum in the Mediterranean region. Reported in Morocco in Azrou, $1300 \mathrm{~m}$ above sea level.

Xanthoria aureala (Ach.) Floerke

Loc. 1, 2, 3, 13.

Nitrophilous. Very widespread in the Mediterranean region, penetrates into fairly warm spots in the Eurosiberian region. 
Xanthoria elegans (Link.) Th. Fr.

Loc. 6, 7.

On horizontal or sloping surfaces in ussually sunlit places. Oro-, helio-, nitrophilous. Artic-Alpine-oro-Mediterranean.

Xanthosporella llimonae Hertel, Egea \& Poelt, Stud. Geobot. 7, suppl. 1: 242 (1987). Loc. 6, 9.

Prefers somewhat sloping to vertical surfaces, with small channels through which water trickles after rain. Optimum in the meso-Mediterranean belt.

The material of Schaereria cinereorufa (Schaer.) Th. Fr. (ut Lecidea [Psora] cinereorufa Schaer.) from the Oued Nefifik (near Boulhaut), Djebel Tangoumait (Assa region) and Tizi Aferni, $1660 \mathrm{~m}$ above sea level (Anti-Atlas) examined by one of us (Egea) in the Werner herbarium (in $\mathrm{BC}$ ) no doubt corresponds to Xanthosporella llimonae.

\section{ACKNOWLEDGEMENTS}

We wish to express our thanks to the Institut Botànic de Barcelona for the loan of material from the Werner Herbarium used in this study; to Dr. X. Llimona (Barcelona) for allowing us to use his file of lichens from North Africa; to Dr. H. Mayrhofer (Graz) for checking the species of the Rinodina genus.

\section{BIBLIOGRAPHY}

Asta, J., P. Ozenda \& G. Clauzade (1972). Lichens du Sud-Ouest marocain. Rev. Bryol. Lichénol. 38(2): 299-303.

Barbero, M., P. QuÉzel \& S. Rivas-Martínez (1981). Contribution à l'étude des groupements forestiers et préforestiers du Maroc. Phytocoenologia, 9 (3): 311-412.

BENABID, A. (1982). Bref aperçu sur la zonation altitudinale de la végétation climacique du Maroc. Ecologia Mediterranea 8(1-2): 301-315.

Bouly DE Lesdain, M. (1924). Lichens du Maroc recuellis par M. Mouret en 1912. Mém. Soc. Sci. Nat. Maroc 8: 290-299.

Bouly de Lesdain, M. \& J. C. Pitard (1913). Lichens. In: Pitard, J. C. (Ed.), Exploration scientifique du Maroc. Fascicule 1 (Botanique): 153-163. París.

Cholsy, M. \& R. G. Werner (1931). Solenospora montagnei (E. Fr.) Choisy et R. G. Werner nov. comb. et le genre Solenospora (Mass.) emend. Choisy et Werner. Bull. Soc. Hist. Nat. Afrique du Nord 22: 7-12.

Clauzade, G. \& Cl. Roux (1981). Les Acarospora de l'Europe occidentale et de la région méditerranéénne. Bull. Mus. Hist. Nat. Marseille 41: 41-93.

Dibben, M. J. (1980). The chemosystematics of the lichens genus Pertusaria in North America north of Mexico. Milwaukee Public Mus. Pub. Bot. 5: 1-162.

EgEA, J. M. (1984). Contribución al conocimiento del género Caloplaca Th. Fr. en España. Especies saxícolas. Collect. Bot. (Barcelona) 15: 173-204.

EgEA, J. M. \& X. Llimona (1981). Claves analíticas de los líquenes de rocas silíceas no volcánicas del SE de España. Anales Univ. Murcia, Ciencias, 37 (1-4): 183-218.

EgeA, J. M. \& X. Llimona (1981). Líquenes silicícolas de la Sierra de los Filabres y Sierra de Alhamilla (Almería, España). Anales Univ. Murcia, Ciencias, 37: 107-152. Murcia.

Egea, J. M. X. Llimona \& M. CaSARes (1982). Aportación al conocimiento de la flora liquénica silicícola de la parte culminal de Sierra Nevada. Collect. Bot. (Barcelona) 13 (1): 295-312.

Hawksworth, D. L., P. W. JAMES \& B. J. Coppins (1980). Check-list of British lichen-forming, lichenicolous and allied fungi. Lichenologist 12(1): 1-115. 
Llimona, X (1979). Roger-Guy Werner (1901-1977) Note biographique et bibliographique. Collect. Bot. (Barcelona) 11: 475-509.

MAHEU, J. (1928). Contribution à la lichénologie du Rif (Maroc). Cavanillesia 1: 56-59.

Maheu, J. \& A. Guillet (1924). Contributions à l'étude des lichens du Maroc. I. Mém. Soc. Sci. Nat. Maroc 8(2): 279-289.

MAHEU, J. \& A. Guillet (1925). Contributions a l'étude des lichens du Maroc. II. Bull. Soc. Bot. France 72: 858-871.

MAHEU, J. \& R. G. Werner (1934 a). Contribution à la flore cryptogamique du Maroc. Fascicule 10 (Lichenes et Algae) Bull. Soc. Sci. Nat. Maroc 14 (4-6): 147-155.

Maheu, J. \& R. G. Werner (1934 b). Etude sur la végétation cryptogamique du Massif du Siroua (Anti-Atlas) Bull. Soc. Sci. Nat. Maroc 14 (7-8): 214-235.

MAYRHOFER, H. (1984). Die saxicolen arten der Flechtengattungen Rinodina und Rinodinella in der Alten Welt. J. Hattori Bot. Lab. 55: 327-493.

Mayrhofer, H. \& J. Poelt (1979). Die saxicolen Arten der Flechtengattung Rinodina in Europa. J. Cramer. Vaduz.

Ozenda, P. \& G. Clauzade, (1970). Les lichens, étude biológique et flore illustrée. Masson \& Cie. París.

PoElT, J. (1969). Bestimmungschlüssel Europäischer Flechten. J. Cramer. Lehre.

SANTESSON, R. (1984). The lichens of Sweden and Norway. Stockholm \& Uppsala.

Swinscow, T. D. W. \& H. Krog (1979). The lichen genera Heppia and Peltula in East Africa. Norw. J. Bot. 26: 213-224.

Szatala, O. (1929). Enumeratio Lichenum a el barone G. de Andréanszky in Africa boreale lectorum. Magyar Bot. Lapok 28: 162-167.

Szatala, O. (1931). Lichens du Maroc recueillis par M. le baron G. Andréansky en 1930. Magyar Bot. Lapok 30: 115-126.

Trotet, G. (1965): Première liste des lichens de Tarfaya (Maroc). Rev. Bryol. Lichénol. 33 (3-4): 597-606.

WALTER H., E. HARNICKELl \& D. HuEller-Dombois (1975). Klimadiagramkarten, G. Fischer. Stuttgart.

WERNER, R. G. (1932 a). Contribution à la flore cryptogamique du Maroc. Fascicule 5. Cavanillesia 5(5): 157-174.

WERNER, R. G. (1932 b). Contribution à la flore cryptogamique du Maroc. Fascicule 7. Rev. Bryol. Lichénol. 5(4): 210-228.

WERNER, R. G. (1934 a). Contribution à la flore cryptogamique du Maroc. Fascicule 10 (Lichenes et Algae) Bull. Soc. Sci. Nat. Maroc 14 (4-6): 147-155.

WERNER, R. G. (1934 b). Étude sur la végétation cryptogamique du Massif du Siroua (Anti-Atlas) Bull. Soc. Sci. Nat. Maroc 14 (7-8): 214-235.

WERNER, R. G. (1936 a). Contribution à la flore cryptogamique du Maroc. Fascicule 13 (Algae, Lichenes, Fungi) Bull. Soc. Sci. Nat. Maroc 16 (1): 90-99.

WERNER, R. G. (1936 b). Contribution à la flore cryptogamique du Maroc. Fascicule 16. Bull. Soc. Sci. Nat. Maroc 16 (4): 256-265.

WERNER, R. G. (1938). Contribution à la flore cryptogamique du Maroc. Fascicule 17 (Algae, Lichenes, Fungi). Bull. Soc. Sci. Nat. Maroc 18 (2): 126-135.

WERNER, R. G. (1939). Contribution à la flore cryptogamique du Maroc. Fascicule 18. Étude biogéographique et écologique sur la flore lichénique de la région de Tanger. Bull. Soc. Sci. Nat. Maroc 19. (1):
$40-53$.

WERNER, R. G. (1948). Les origines de la flore cryptogamique du Maroc d'après nos connaissances actuelles. Vol. Jubil. Soc. Sci. Nat. Maroc 1920-1945: 147-202.

WERNER, R. G. (1954). Lichens et champignons nord-africains. Rev. Bryol. Lichénol. 23 (1-2): 197-213.

WERNER, R. G. (1955). Contribution à la flore cryptogamique du Maroc. Fascicule, 19. Bull. Soc. Sci. Nat. Phys. Maroc 35 (1): 19-67.

WERNER, R. G. (1956). Contribution à la flore cryptogamique du Maroc. Fascicule, 20. Lichens de l'Anti-Atlas. Bull. Soc. Hist. Nat. Afr. Nord 47 (34): 84-91.

WERNER, R. G. (1957). Contribution à la flore cryptogamique du Maroc. Fascicule 21. Bull. Soc. Hist. Nat. Afrique du Nord 48 (7-8): 441-453.

WERNER, R. G. (1963). Flore lichenique du Maroc meridional. Rev. Bryol. Lichénol 32 (1-4): 270-278.

Werner, R. G. (1967). Lichenes et fungi maroccani II. Bull. Soc. Mycol. France 83 (2): 242-256.

WERNER, R. G. (1968). Lichenes et fungi maroccani annis 1931-1935 a Cl. J. Gattefossé et M. Zaborski lecti. Rev. Bryol. Lichénol. 36 (1-2): 304-313. 
WERNER, R. G. (1972). Lichens et champignons de la plaine maroccaine. Bull. Acad. et Soc. Lorraines Sci. 10 (2): 83-97.

Werner, R. G. (1974). Flore lichénologique du Moyen-Atlas central. Bull. Soc. Mycol. France 90 (1): 49-66.

WERNER, R. G. (1979). La flore lichénique de la cordillère bético-rifaine. Étude phytogéographique et écologique. Collect. Bot. (Barcelona) 11: 401-463.

Wetmore, Cl. M. (1970). The lichen family Heppiaceae in North America. Ann. Missouri Bot. Gard. 57: 158-209. 